\title{
The Effect of Cooperative Learning Model of Teams Games Tournament (TGT) and Students' Motivation toward Physics Learning Outcome
}

\author{
Nadrah $^{1}$, Ismail Tolla ${ }^{1}$, Muhammad Sidin Ali $^{1} \&$ Muris $^{1}$ \\ ${ }^{1}$ Educational Science, Universitas Negeri Makassar, Indonesia \\ Correspondence: Nadrah, Educational Science, Universitas Negeri Makassar, Indonesia. E-mail: \\ nadrahelhafidy14@gmail.com
}

Received: May 5, 2016

Accepted: June 20, 2016

Online Published: January 30, 2017

doi:10.5539/ies.v10n2p123

URL: http://dx.doi.org/10.5539/ies.v10n2p123

\begin{abstract}
This research aims at describing the effect of cooperative learning model of Teams Games Tournament (TGT) and motivation toward physics learning outcome. This research was a quasi-experimental research with a factorial design conducted at SMAN 2 Makassar. Independent variables were learning models. They were cooperative learning model of TGT and conventional learning model. Motivation as moderator variable was divided into two factors, namely high and low learning motivation. The dependent variable was physics learning outcome. The instrument was a questionnaire of motivation to learn physics used to measure the motivation of students. Whereas physics achievement test was used to measure the physics learning outcome of the students. There were 36 students of class $\mathrm{X}$ in SMAN 2 Makassar taken using random sampling techniques as the research samples. The data were analyzed using two ways of ANOVA. There were some findings of this research. First, the physics learning outcome of the students taught using cooperative learning model TGT was higher than students taught using conventional learning models. Second, the physics learning outcome of students who had high motivation to learn physic and were taught using cooperative learning with TGT was higher than students taught using conventional learning model. Third, the physics learning outcome of students who had low motivation to learn physic and were taught using cooperative learning with TGT was not significantly lower than students taught by conventional learning model. However, the learning outcome between those two learning models were significantly different with $\alpha=0,05$. Fourth, there was a significant interaction effect between learning model and motivation toward physics learning outcome of the students.
\end{abstract}

Keywords: learning model, learning motivation, physics learning outcome

\section{Introduction}

Physics learning outcome at SMAN 2 Makassar still requires serious attention and treatment. Based on the data, the mean score of the physics learning outcome for the final exam at the end of the second semester of the academic year 2013-2014 was 55.1 at the level of class X (ten). It means that the mean score is still below the standard of the minimum for completeness criteria, while the completeness criteria determined by the school is 70 , especially for physics subject at SMAN 2 Makassar.

Learning physics at SMAN 2 Makassar during observation, in general, is almost the same as the direct instruction. There are some learning steps of direct instruction. First, the teachers prepare the students to accept the lesson. Second, the teachers and the students pray together. Third, the teachers demonstrate the learning materials. Fourth, the teachers give some examples. Fifth the students do the students' worksheet given by teachers. Sixth, the teachers give homework. In this paper, the direct instruction according to the authors refers to the conventional learning model.

In relation to the above description, every teacher must have expertise in selecting teaching methods that are always used every day. Selection of the right learning model is oriented to teaching purposes, including the purpose of each material to be covered each meeting given to learners. From some existing learning models, cooperative learning model of TGT is important to be known as the best solution to improve motivation and learning outcomes of physics students. In this model, the students not only listen to the explanation of the teacher that often makes students bored and even become passive but also must be involved as peer tutors. This model 
also contains elements of games and reinforcement. Moreover, the students are taught to express their opinion. This model can train the ability of learners in games that will be able to increase their motivation and in turn the learning outcome increases. This learning model has five stages that must be passed by the students. The first stage is class presentation. The second stage is learning in groups or teams. The third stage is playing games. The fourth stage is a tournament. This stage is the most memorable for the students because students will perform as much as possible to represent the group competing to take points collected for their group, and the points will be joined with friends' points in their group. The fifth stage is teams' recognition, in which the students feel the importance of cooperative learning of TGT because they feel compelled to study physics because their group can be a super team with an average score of 50 . It can be a great team with the mean score of 45 . In addition, it can be a good team with the average score of 40 (Slavin, 2005, p. 176)

Based on the description above, the authors tried to examine the condition of the realities faced by students towards physics lesson. The issue was raised as research material entitled "the effect of cooperative learning model with Teams Games Tournament (TGT) and motivation toward physics learning outcome (Experimental Study on Class X SMA Negeri 2 Makassar".

\section{Research Method}

This research was a quasi-experimental research with a factorial design conducted at SMAN 2 Makassar. The populations of this research were all students at class X (ten) SMAN 2 Makassar consisting of 9 classes and the total of the students is 288 . The researchers used simple random sampling technique. The steps of conducting this research were:

a. The researchers randomly selected two of the nine classes in class ten at SMAN 2 Makassar. Based on this randomization, the selected classes were class X3 and X9. Randomization was conducted in order that the research activities do not interfere with the learning process too much.

b. The researchers randomly choose the class that was treated using cooperative learning model of TGT and the class that was treated using traditional learning. Based on the randomization, class X3 was selected to be treated using TGT and class X9 was chosen to be treated using traditional learning.

c. The researchers distributed questionnaires in each treatment group to determine whether the students had high or low motivation. The determination of the number of students who are categorized as high and low motivation in both the TGT cooperative learning model and the conventional learning models was respectively $27 \%$ of the total number of the regular students.

There were three variables in this research, namely:

a. Independent variable was learning models in the form of cooperative learning of TGT and conventional learning model.

b. The dependent variable was the students' learning outcome.

c. The moderator variable was learning motivation with a high and low level of learning motivation.

The instruments were the questionnaires on motivation to learn physics and physics achievement test. The details of the research instruments used to collect data were as follows.

\section{1) Questionnaire on motivation to learn physics}

This instrument was used to measure the level of motivation of learners. Motivation to learn physics questionnaire was given to students in two classes at the beginning of the meeting. These questionnaires consist of 36 items developed by researchers based on indicators of motivation to learn physics. This questionnaire has been validated by the experts of research methodology. Scale motivation to learn physics in this study was designed based on Likert scale models that contain a statement indicating the number of objects to be revealed. It is provided five possible answers to measure the learning motivation, namely strongly agree $=5$, agree $=4$, neither agree nor disagree $=3$, disagree $=2$, and strongly disagree $=1$.

The questionnaire is based on indicators of the motivation to learn physics. Before using the questionnaire, it must first be validated by a validator then conducted empirical testing to see the validity and reliability of the instrument so that the items of the questionnaire are eligible to be used as data collection tool. The test results were analyzed by using Pearson Product Moment to determine the validity of the items and Cronbach Alpha to determine the reliability of the instrument. Each statement was then analyzed on the distribution of respondents.

2) Questionnaire on physics achievement test

Physics achievement test was a test used to measure the ability of learners within a certain time after the TGT 
cooperative learning model and conventional learning models were applied. It was in the form of objective test namely multiple choice as many as 20 items in accordance with the material. This test was given at the end of the meeting after applying treatment in each class research.

Before being used, the instrument must first be validated by the validator and then tested to see the validity and reliability of the instrument so it could be said that the learning outcome of physics deserved to be used as a data collection tool.

Data obtained from physics learning outcome were analyzed quantitatively in order to describe the characteristics of learners score after these two learning models were implemented. After the data was collected, the next step is to analyze and process data.

\subsection{Try-Out}

The instruments used in this study were in the form of physics achievement test and questionnaire containing motivation to learn physics. Before these Instruments being used, it must be first conducted try-out outside the sample but it was still in the population to determine the content validity and empirical validity of the instrument. The try-out was held at SMAN 2 Makassar that was not included in the sample of this research. It was conducted at class X1, X2, X4, X5, X6, X7, X8.

\subsection{Content Validity}

Expert validation results of the questionnaire on motivation to learn physics and physics achievement test had some objectives as follows.

a. To observe carefully all items in the instrument to be validated

b. To correct the interpretation of the items that have been made

c. To give consideration whether the instruments are worthy or not and to outline the scope to be measured.

The analysis of the consistency between the experts was carried out by using the internal consistency of Gregory. The framework used to assess the concept aimed at reviewing the concept, dimensions and items of the instruments. Each expert was asked to fill the consistency between the items, dimensions, and existing theoretical construction. A scoring scale was the range of 1 to 4 . The score was four if it was very relevant. The score was three if it was relevant. The score was two if it was less relevant. The score was one if it was not relevant.

Some experts, Lawshe and Martuza (Ruslan, 2009) discuss the statistical methods to determine the content validity and internal consistency coefficient of a test through expert assessment. The relevance of both experts was thoroughly internal consistency proposed by Gregory. Internal consistency coefficient could be calculated by using compatibility between two experts. The formula that was used was as follows.

$$
\text { internal consistency coefficient }=\frac{\mathrm{D}}{\mathrm{A}+\mathrm{B}+\mathrm{C}+\mathrm{D}}
$$

The measuring devices were consistent if the internal consistency coefficient was more than $75 \%$ (Ruslan, 2009, p. 19)

In addition, in analyzing the research instrument it also noticed the advice of the validator. The suggestions served as guidance in revising the research instruments.

\subsection{Instrument of Motivation to Learn Physics}

Based on calculations of all items of the questionnaire on motivation to learn physics by using the Gregory formula, it was obtained internal consistency coefficient of 0.9. It proved that the questionnaire was consistent.

\subsection{Instrument of Physics Learning Outcome}

Based on calculations of all items of the physics test by using the Gregory formula, it was obtained internal consistency coefficient of 1,0 . It proved that the questionnaire was consistent.

\subsection{Empirical Validity and Reliability Test}

\subsubsection{Instrument of Motivation to Learn Physics}

After obtaining a valid instrument based on the opinions of experts, it was then conducted equivalent tests on respondents. Data of students' motivation to learn physics was obtained from questionnaires given to 240 respondents. This data were analyzed by using the average percentage. In addition, the data were sorted from high learning motivation to low learning motivation. After being sorted, it was taken $27 \%$ students who had high 
motivation to learn physics and $27 \%$ students who had low motivation to learn physics. The data were used for further analysis to determine the effect of TGT cooperative learning model and conventional learning model for students who had high and low motivation to learn physics.

After weighting had been conducted, product moment correlation formula proposed by Pearson was used to determine whether each item and the reliability of the questionnaire on motivation to learn was valid or not. Scores were obtained in such a manner by using product moment correlation with the help of Microsoft Excel program. After obtaining the score of $r$ calculation, it was then compared with $r$ table with a significance level of $5 \%$. The validity was achieved if $r_{\text {count }}>r_{\text {table. }}$. The formula of product moment correlation is as follows.

$$
\mathrm{r}_{\mathrm{xy}}=\frac{N \sum X Y-\left(\sum X\right)\left(\sum Y\right)}{\sqrt{\left\{N \sum X^{2}-\left(\sum X\right)^{2}\right\}\left\{N \sum Y^{2}-\left(\sum Y\right)^{2}\right\}}}
$$

(Sudijono, 2006).

Notes:

$\mathrm{r}_{\mathrm{xy}}=$ The correlation score of product moment

$X \quad=$ The score obtained by each respondent for each item

$Y \quad=$ The total of score obtained by each respondent for each item

$N \quad=$ The total of respondents

Based on the total of respondents, the $r$ table is 0,35 . Based on the results of the empirical testing for motivation to learn physics of the 40 items tested on 240 respondents with a significance level of 0.05 , it was found four items that were not valid namely item 17, 24, 25, and 29 because $r$ count is less than $r$ table $\left(r_{\text {count }}<r_{\text {table }}\right)$.

Reliability of the instrument of motivation to learn physics could be calculated using the Alpha Crombach formula. The formula was as follows.

$$
r_{11}=\frac{n}{n-1}\left(1-\frac{\sum_{i=1}^{n} \sigma_{i}^{2}}{\sigma_{t}^{2}}\right)
$$

(Crocker \& Algna, 2008, p. 121)

Notes:

$\mathrm{r}_{11}=$ The reliability coefficient

$n \quad=$ The total of items

$\sigma_{i}{ }^{2}=$ Scores variance item to-i

$\sigma_{t}{ }^{2}=$ Total of scores variance

The coefficient of reliability on the test questionnaire of motivation to learn physics was 0.89 . Based on the results of reliability analysis, it could be concluded that the questionnaire that had been used was reliable. Thus, the number of items of learning motivation questionnaire used in this study was as much as 36 items.

\subsubsection{Instrument of Physics Learning Outcome}

After obtaining valid targets through experts' opinion, then it was then conducted try-out at the equivalent of respondents. Because the data collected were the results of the objective test, so the data were computed using point biserial correlation coefficient (rpb) with the help of Microsoft Excel program.

$$
r_{p b i s}=\frac{\left(\bar{x}_{t}-\bar{x}_{i}\right)}{s_{t}} \sqrt{\frac{p}{q}}
$$

(Crocker \& Algna, 2008, p. 317).

Notes:

$\overline{X_{t}} \quad=$ Mean total scores of participants who have the correct answer

$X_{i} \quad=$ Mean score

$S_{t} \quad=$ Standard deviation scores 
$p \quad=$ The proportion of participants who answered correctly on the test item

$q \quad$ The proportion of participants who answered incorrectly or (1-p)

Point biserial correlation coefficients were obtained for each item compared with a correlation coefficient that was in the $r$ table with a significance level of $5 \%$. If the correlation coefficient between the scores of items and the total score was higher than r-table, the items are valid. On the contrary, if the scores of the items were lower than $r$ table, the test item could not be used.

Based on the results of similar tests on respondents of the 20 items on the learning outcomes that was tested to 120 respondents, all items were stated valid.

Reliability achievement test was determined using the formula Kuder-Richardson 21 (KR-21) with the help of Microsoft Excel program. KR-21 formula formulated by Kuder and Richardson in Mardapi (2012, p. 73) was as follows.

$$
K R-21=\frac{k}{k-1}\left(1-\frac{k P(1-P)}{S_{x^{2}}}\right)
$$

(Crocker \& Algna, 2008, p. 139).

Notes:

$\mathrm{k} \quad=$ The number of test items

$S_{X}{ }^{2}=$ Variance scores

$\mathrm{P} \quad=$ The mean proportion of participants with correct answers to each item.

Based on the results of the analysis of reliability, the reliability coefficient was equal to 0.911 . Therefore, it could be concluded that the test used to get learning outcome was reliable. Hence, there were 20 items of learning outcome used in this research.

\subsection{Data Collection Techniques}

The data that were collected in this study were the data on physics learning outcome obtained by using physics achievement test. While data regarding the motivation to learn physics was obtained by using questionnaires.

\subsection{Data Analysis Techniques}

Data were analyzed using inferential statistical analysis. The inferential statistical analysis was intended to test the hypothesis in this research using Two Ways Anova. If $\mathrm{H} 0$ is rejected (there are differences), there must be advanced Tukey testing to find out the differences. On the contrary, if $\mathrm{H} 0$ is accepted (there are no differences) there must not be advanced Tukey testing

\section{Results}

Test this hypothesis by using statistical methods performed using Two Ways Anova. It was followed by t-test to find out the main effect that was higher and also proceed by using Tukey test. The results of Two Ways Anova can be seen in the following table.

Table 1. Analysis of two ways Anova

\begin{tabular}{lccccc}
\hline Source of variance & Sum of squares (JK) & df & Average squared (RK) & Fh & Ft \\
\hline Learning model (k) & 36 & 1 & 36 & $12.34^{*}$ & 4.15 \\
Motivation (b) & 11.1112 & 1 & 11.1112 & $3.81^{\#}$ & 4.15 \\
interaction bxk & 75.1110 & 1 & 75.1110 & 25.75 & 4.15 \\
Errors (in cells) & 93.3334 & 32 & 2.9166 & - & - \\
Total & 215.5556 & 35 & - & - & - \\
\hline
\end{tabular}

\footnotetext{
Notes:

$\mathrm{dk}=$ degrees of freedom

$\mathrm{Fh}=\mathrm{F}$ count

$\mathrm{Ft}=\mathrm{F}$ table

$*=\mathrm{F}$ test of significance

\# $=\mathrm{F}$ test not significant
} 
It is stated significant if $F$ count is more than or equal to $F(\geq F)$ with the significance level is 0.05 . Based on the calculation in the above table, the hypothesis testing is as follows:

1) For the first hypothesis, learning outcomes of physics learners taught using cooperative learning model with Teams Games Tournament is overall higher than in the learning outcomes of physics learners taught using conventional learning models. Based on the calculation using ANOVA, it shows that the F count is 12.34 and it is higher than $\mathrm{F}$ table because $\mathrm{F}$ table is 4.15 ( $\mathrm{F}$ count $=12.34>\mathrm{F}$ table $=4.15$ ). It means that it is rejected or accepted. Therefore, there is a significant difference. To strengthen the influence of the higher learning model, it is followed by $t$-test. Based on the $t$-test, it is found that $t$ count is 2.61 . Meanwhile, based on the $\mathrm{t}$-distribution table with the significance level is 0.05 and degree of freedom is 32 , it is found that $t$ table is 1.692 (Interpolation). This hypothesis is rejected or accepted because $\mathrm{t}$ count $=2.61>\mathrm{t}$-table $=$ 1.692. Therefore, there is a significant influence on the level $=0.05$.

2) For the second hypothesis, the students who have high motivation to learn physics and taught using cooperative learning with TGT model have higher learning outcome than the students taught using conventional learning models. Based on calculations of Tukey test, the mean score for the group of students who have high motivation to learn physics toward the physics learning outcomes using cooperative learning model with TGT is 19.1111 (group I). Whereas, the mean score for the group of students who have high motivation to learn physics toward the physics learning outcomes using conventional learning models is 14.2222 (group II). It is found that the mean squared in two ways ANOVA is 2.9167. Therefore, the score of Q-count is 8.59 . Because the significance level is 0.05 and degree of freedom is 34 , and then the value of Q-table is 3.826 (Interpolation). Because the value of Q-count is higher than Q-table $(8.59>3.826)$, then it is rejected or accepted. Therefore, there is a significant difference.

3) For the third hypothesis, the students who have low motivation to learn physics and taught using cooperative learning with TGT model have higher learning outcome than the students taught using conventional learning models. Based on calculations of Tukey test, the mean score for the group of students who have high motivation to learn physics toward the physics learning outcomes using cooperative learning model with TGT is 15.1111 (group III). Whereas, the mean score for the group of students who have high motivation to learn physics toward the physics learning outcomes using conventional learning models is 16.00 (group IV). It is found that the mean squared in two ways ANOVA is 2.9167. Therefore, the score of Q-count is 1.56 . Because the significance level is 0.05 and degree of freedom is 34 , and then the value of Q-table is 3,826 (Interpolation). Because the value of Q-count is lower than Q-table $(1.56<3.826)$, then it is rejected or accepted. Furthermore, in order to know whether there is a significant difference or not, therefore there is a significant difference. Mean scores between the two cells are tested using t-test. The criteria of the testing is that $\mathrm{H} 0$ is accepted if $\mathrm{t}$ table $<\mathrm{t}$ count $<+\mathrm{t}\urcorner$ table in which $\mathrm{t}$ table is obtained from distribution list $t$ with the degree of freedom is $(\mathrm{db})=\mathrm{n} 1+\mathrm{n} 2-2$ and the opportunity of the other value is rejected. Although the students who have low motivation to learn physics and taught using cooperative learning model with TGT have learning outcomes that are not significantly lower than the students taught using traditional learning the learning outcomes of the two cells are significantly different at the significance level of $0.05(\alpha=0.05)$.

4) For the fourth hypothesis, there is an interaction effect between learning model and motivation toward learning outcomes. Based on the calculation results using two ways Anova, it is found that the value of $\mathrm{F}$-count is 75.1110 . For the significance level of 0.05 , it is found that $\mathrm{F}$ table is 4,15 . Because $\mathrm{F}$ count is higher than F table $(75.1110>4.15)$, it is rejected or accepted. Therefore, there is a significant interaction. It means that there is an interaction effect between learning model and motivation toward learning outcomes.

\section{Discussion}

\subsection{Hypothesis I}

Based on the hypothesis testing, it is found that the first hypothesis is rejected. It means that physics learning outcomes of students taught using cooperative learning model with TGT are overall higher than the students taught using conventional learning models. This finding is in line with the previous study as the research conducted by Pranata (2012) in which his finding shows that cooperative learning model with TGT can improve motivation and learning outcomes. According to Hopkins (Noornia, 1997, p. 14) TGT is a form of cooperative learning where once students learn individually, and then each member of the group held a tournament with other group members according to their ability level. 


\subsection{Hypothesis II}

Based on the hypothesis testing, it is found that the first hypothesis is rejected. It means that the students who have high motivation to learn physics and taught using cooperative learning with TGT model have higher learning outcome than the students taught using conventional learning models. This finding is in line with the previous study as the research conducted by Siahaan, and Roma Mawarni Arta entitled "the influence of learning model with Teams Games Tournament toward the learning outcomes in collaboration with colleagues and customers of students of class X at private vocational school in Medan". Their finding shows that learning outcomes of the students taught by using TGT are higher than the students taught by using conventional methods. Slavin in Huda (2011) reveals that the cooperative learning model with TGT helps the learners to review and master the learning material. It also helps the learners to improve basic skills-skills, achievement, positive interaction between learners, self-esteem, and acceptance of the other different learners. Cooperative learning with TGT requires thorough preparation. It is different from the conventional model that has been put forward the methods of lecturing and giving assignments. Some teachers choose TGT because this model is pleasant. Some games are packed in a tournament so that it can enable learners to be active in the class.

\subsection{Hypothesis III}

Although the students who have low motivation to learn physics and taught using cooperative learning model with TGT have learning outcomes that are not significantly lower than the students taught using traditional learning the learning outcomes of the two cells are significantly different at the significance level of 0.05 ( $\alpha=$ $0,05)$. This finding is in line with the previous study as the research conducted by Niken Ratna Wijaya entitled the relationship between motivation and learning outcomes of students in the subjects Civic Education at SMPN 77 Jakarta. She concludes that learning motivation is one of the contributing factors to improve student learning outcomes. Although the learning motivation is low, it is a factor that affects learning outcomes. In addition, other supporting factors can improve the learning outcomes of students. They come from outside the self-learners. In the concept of learning, motivation is the art of encouraging learners to learn activities so that the learning objectives can be achieved (Rasyad, 2003, p. 92). Even though the learners have low motivation, they felt encouraged to study hard if they got the spirit and stimulation from the outside, especially from teachers. Usman (2011, p. 21) states that in creating effective learning conditions, five variables determine the success of students, namely involving learners to be active, attracting the interest and attention, arousing motivation and attention to the ability of learners and using appropriate teaching media

\subsection{Hypothesis IV}

Based on the hypothesis testing, the fourth hypothesis is rejected. It means that there is an interaction effect between learning model and motivation toward learning outcomes. This finding is in line with the previous study conducted by Andina Wahyu Widyasari entitled "The comparison of the use of cooperative learning model with Teams Games Tournament (TGT) and Student Team Achievement Division (STAD) toward students learning outcomes on Natural Science at SMPN 2 Lendah". Her finding shows that there are significant differences between classes using TGT model, STAD, and conventional learning model. Slavin in Rusman (2013, p. 201) states that the cooperative learning to promote learners to interact actively and positively in the group. In this fun activity, students feel more motivated to learn and think.

\section{Conclusion}

Based on the results and discussions above, some conclusions can be drawn, namely:

a. Physics learning outcomes of students taught using cooperative learning model with TGT are overall higher than the students taught using conventional learning models.

b. The students who have strong motivation to learn physics and taught using cooperative learning with TGT model have higher learning outcome than the students taught using conventional learning models.

c. Although the students who have low motivation to learn physics and taught using cooperative learning model with TGT have learning outcomes that are not significantly lower than the students taught using conventional learning the learning outcomes of the two cells are significantly different at the significance level of $0.05(\alpha=0,05)$.

d. There is an interaction effect between learning model and motivation toward learning outcomes.

\section{References}

Anderson, L. W., \& Krathwohl, D. R. (2001). A Taxonomy for Learning, Teaching, and Assessing. A Revision of Bloom's Taxonomy of Educational Objectives. New York: Addison Weley Longman, Inc. 
Arsyad, A. (2011). Media Pembelajaran. Jakarta: Rajawali Pers.

Asri, B. (2004). Belajar Dan Pembelajaran. Jakarta: Rineka Cipta.

Brophy, J. (2004). Motivating Student to Learn (2nd ed.). London: Lawrence Erlbaum Associates, Publishers.

Crocker, L., \& Algna, J. (2008). Introduction to classical and modern test theory. Ohio: Cengage Learning

Fraenkel, J. R., \& Wallen, N. E. (2009). How To Design and Evaluate Research In Education. New York: McGraw-Hill Companies, Inc.

Huda, M. (2011). Model-Model Pengajaran dan pembelajaran Isu-Isu Metodis dan Paradigmatis. Yogyakarta: Pustaka Pelajar.

Mardapi, D. (2012). Pengukuran Penilaian \& Evaluasi Pendidikan. Yogyakarta: Nuha Litera.

Mehrens, W. A., \& Lehmann, I. J. (1973). Measurement and evaluation in education and psychology. New York: Hold, Rinehart and Wiston, Inc.

Pranata, C. A. (2012). Penerapan Model Pembelajaran Kooperatif Tipe Teams Games Tournament (TGT) untuk meningkatkan motivasi dan hasil belajar IPA di SMPN. 1 Ngaglik Sleman. Retrieved from http://eprints.uny.ac.id/8342/1/halaman\%20depan.pdf

Ruslan. (2009). Validitas isi. Bulletin Pa'biritta, Nomor 10 tahun, VI, 18-19.

Rusman. (2013). Model-Model Pembelajaran Mengembangkan Profesionalisme Guru. Bandung, PT. Raja Grafindo Persada.

Slavin, R. E. (2005). Cooperative Learning Teori, Riset dan Praktik. Bandung: Nusa Media.

Usman, M. U. (2011). Menjadi Guru Profesional. Bandung, PT. Remaja Rosda Karya.

\section{Copyrights}

Copyright for this article is retained by the author(s), with first publication rights granted to the journal.

This is an open-access article distributed under the terms and conditions of the Creative Commons Attribution license (http://creativecommons.org/licenses/by/4.0/). 